\title{
Komunikasi Politisi Perempuan di Nusa Tenggara Barat (Analisis Pesan Kampanye Politik Dr. Hj Sitti Rohmi Djalillah Dalam Kontestasi Pemilihan Gubernur Tahun 2018/2019)
}

\author{
Depanda Zulvianingrum dan Najamudin \\ Universitas Islam Negeri Mataram \\ depandazulvianingrum@gmail.com. \\ najamudin82@uinmataram.ac.id
}

\begin{abstract}
Abstrak
Pada era demokrasi dengan keterbukaan informasi publik dan kebebasan beraspirasi sehingga Negara menyediakan 30\% quota pada kaum perempuan untuk ikut berpartisipasi dalam pemilu legislatif 2014. Hal ini telah menjadi perhatian yang cukup lama dalam aspirasi-aspirasi bagi para pejuang kesetaraan gender termasuk menjadi cita-cita dan tuntunan bahwa laki-laki dan perempuan memiliki hak yang sama khususnya dalam bidang politik. Dengan ketersedian quota yang dapat mendorong lebih jauh lagi perjuangan bagi kaum perempuan, posisi peran dan aktivitas perempuan Indonesia dalam dunia politik semakin meningkat dalam ukurannya sendiri dari waktu ke waktu di dalam sejarah Indonesia merdeka. Keterwakilan perempuan yang memadai setidaknya dapat memberikan, melengkapi, dan menyeimbangkan visi, misi, dan oprasionalisasi Indonesia selanjutnya yang objektif namun berempati dan berkeadilan gender (tidak mendiskriminasikan salah satu jenis kelamin saja) dan membuktikan bahwa Indonesia memiliki sistem demokrasi yang ramah bagi gender. Sebagai seorang perempuan yang akan maju dalam pilgub 2018 umi Rohmi mengontrol untuk mencapai target kemenangan menggunakan beberapa komunikasi karena perempuan masih dipandang sebagai mahluk second class mahluk kedua di daerah Nusa Tenggara Barat jadi umi Rohmi menggunakan beberapa cara seperti bentuk kampanye yang dilakukannya mulai dari memperkenalkan (mensosialisasikan) diri kepada
\end{abstract}


Komunike, Volume XI, No. 1, Juni 2019

masyarakat, terjun langsung kelapangan atau biasa dikenal dengan istilah blusukan, dan terakhir kerja, bersinergi dengan tim sukses.

Kata kunci: Komunikasi, Politisi Perempuan, Kontestasi 
Komunike, Volume XI, No. 1, Juni 2019

\section{A. Latar Belakang}

Dalam peraturan perundangundangan yang mengatur tentang hak warga Negara dan hak politik perempuan No. 7 Tahun 1998 telah tegas mengatakan tentang penghapusan segala bentuk diskriminasi terhadap perempuan, Kepres No. 36 Tahun 1990 tentang Hak anak, deklarasi penghapusan kekerasan terhadap perempuan yang diadopsi oleh Majelis Umum PBB, termasuk Indonesia pada 1993, Konvensi ILO No. 111 tentang diskriminasi dalam pekerjaan dan jabatan dengan UU No. 21/1999 serta Instruksi presiden No. 9 tahun 2000 Pengarus utamaan Gender dalam Pembangunan Rumah Tanggga.'

Dengan adanya perundangundangan tersebut, perempuan Indonesia memiliki peluang yang

\footnotetext{
${ }^{1}$ Komarudin Hidayat, Demokrasi dan Hak Asasi Manusia dan Masyarakat Madani (Jakarta: Kencana Group, 2006), hlm. 233.
}

besar untuk ikut serta terjun dalam dunia politik. Terlebih dengan Negara yang menganut sistem demokrasi yang kedaulatan tertinggi ada di tangan rakyat dan keputusan-keputusan pemerintah yang penting secara langsung atau tidak langsung didasarkan pada kesepakatan mayoritas yang diberikan secara bebas dari rakyat dewasa.

Pada era demokrasi dengan keterbukaan informasi publik dan kebebasan beraspirasi sehingga Negara menyediakan $30 \%$ quota pada kaum perempuan untuk ikut berpartisipasi dalam pemilu legislatif 2014. Hal ini telah menjadi perhatian yang cukup lama dalam aspirasi-aspirasi bagi para pejuang kesetaraan gender termasuk menjadi cita-cita dan tuntunan bahwa lakilaki dan perempuan memiliki hak 
Komunike, Volume XI, No. 1, Juni 2019

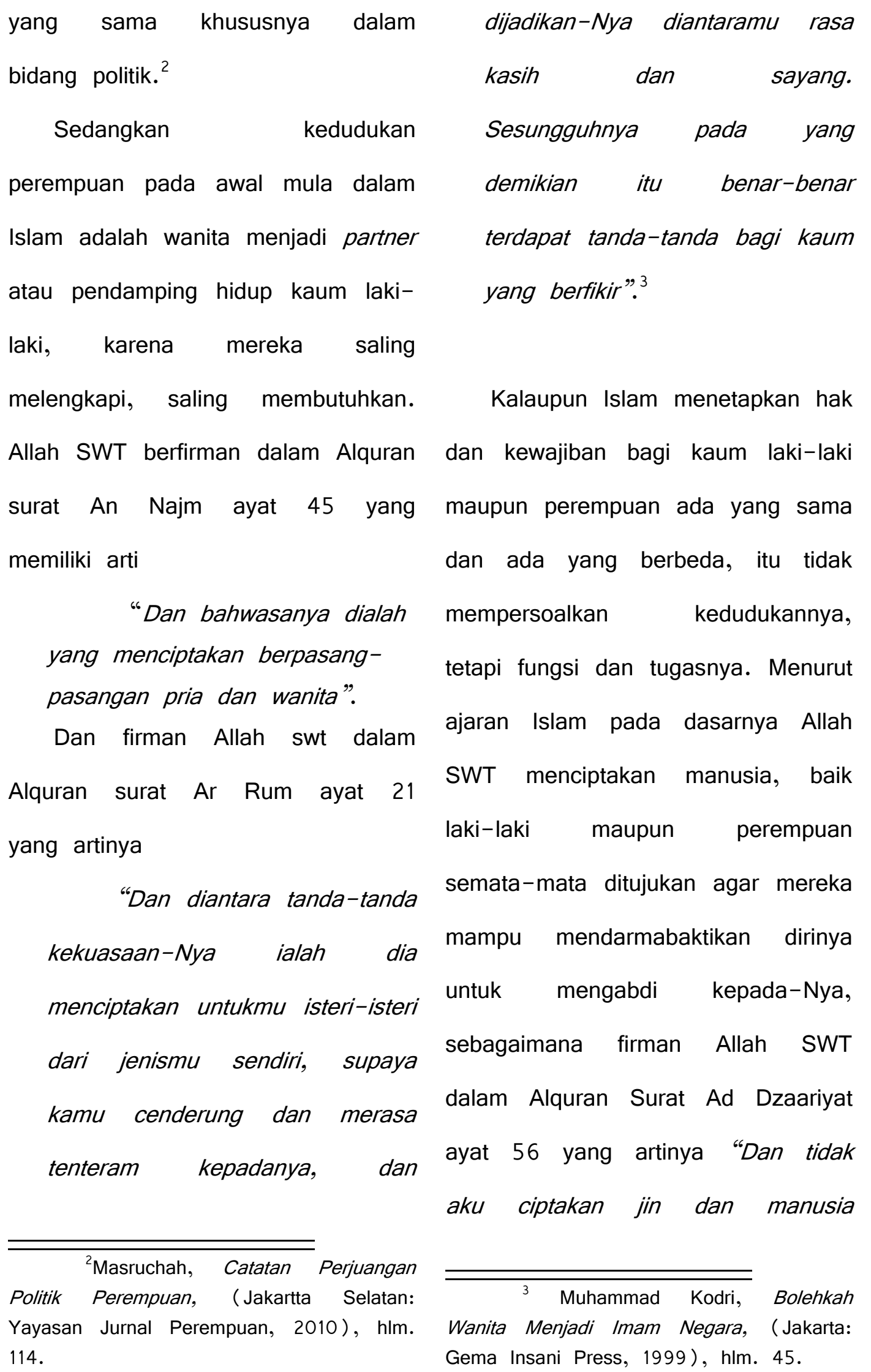


Komunike, Volume XI, No. 1, Juni 2019

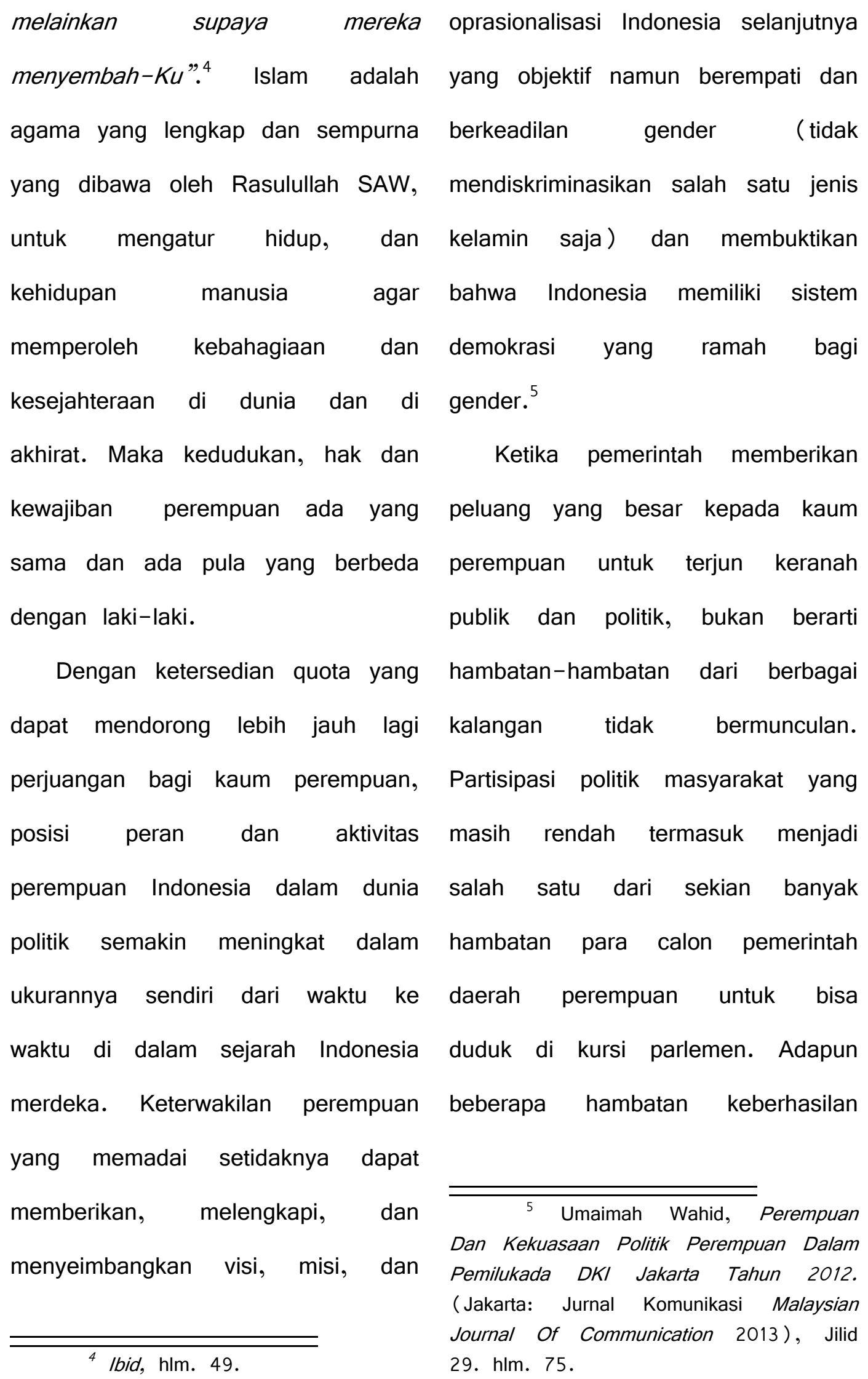


Komunike, Volume XI, No. 1, Juni 2019

partisipasi politik menurut Ani menduduki jabatan tertinggi sebagai Purwanti SH, M.Hum. di antaranya ketua DPRD. Yakni Hj. Baiq Isvie adalah: Pertama, Hambatan nilai Rupaeda berhasil menduduki jabatan sosial budaya, yaitu nilai-nilai, citra tertinggi. $\mathrm{Hj}$ Baiq Isvie resmi baku/pandangan dalam masyarakat melanjutkan sisa masa jabatan yang dipengaruhi oleh budaya Umar Said menjadi ketua DPRD patriarki yang menempatkan laki- NTB . Sidang istimewa pelantikan laki di posisi pemimpin, penentu dewan baru yakni Baiq Isvie dan pengambilan keputusan dengan Rupaeda yang melanjutkan sisa kedudukan superior sehingga jabatan Umar Said tahun 2014perempuan menjadi warga negara $2019 .^{7}$

kelas dua yang didiskriminasikan Bersamaan dengan itu dari 65 dan dimarginalkan (isu gender), orang yang dilantik menjadi anggota termasuk tafsir agama yang bias DPRD Provinsi NTB terdapat 5 gender. Kedua, Faktor manusianya, orang perempuan berikutnya yang dalam hal ini diri perempuan menjabat sebagai anggota DPRD sendiri yang selama ini belum Provinsi NTB yakni, Misfalah dari terkondisikan untuk terjun dan partai Demokrat sebagai anggota berperan di arena politik dan Komisi II Bidang Perekonomian, kehidupan publik. $^{6}$

Dra $\mathrm{Hj}$. Wartiah, MPd dari partai

Dalam history telah terjadi di PPP yang menjabat sebagai ketua gedung DPRD Provinsi NTB untuk Komisi V Bidang Kesejahteraan pertamakalinya, seorang perempuan Rakyat dan Pemberdayaan

$\overline{6 \text { Saparinah Sadli, Pengetahuan }}$ Perempuan, (Jakarta Selatan: Yayasan Jurnal Perempuan, 2006), hlm. 32.
Parempuan,

$\mathrm{Hj}$. Nurlaela isvie 
Komunike, Volume XI, No. 1, Juni 2019

Chaerunnisa, S.E dari partai PKB adalah sebagai power perempuanyang menjabat sebagai anggota perempuan di NTB Pada umumnya Komisi $\quad \mathrm{d}$ dalam bidang untuk menduduki ruang-ruang Kesejahteraan Rakyat dan publik di Nusa Tenggara Barat.

Pemberdayaan Parempuan, $\mathrm{Hj}$. Implikasi yang akan di Suryahartin SP. MAP dari partai timbulkan oleh adanya pengaruh $\mathrm{Hj}$ Nasdem menjabat sebagai anggota Baiq Isvie Rupaeda, bukti nyatanya komisi $\quad V \quad$ dalam bidang adalah adanya wajah baru yaitu $\mathrm{Hj}$ Kesejahteraan Rakyat dan Sitti Rohmi Djalillah yang Pemberdayaan Parempuan, $\mathrm{Hj}$ merupakan wakil pasangan calon Rahmah HM Hanura sebagai $H$ Zulkieflimansyah nomor urut 3 anggota Komisi $V$ yang diketuai pada tahun 2018 bertarung dengan oleh Dra Hj. Wartiah. ${ }^{8}$ Pasca 3 pasangan calon lainnya dalam dinyatakan naik $\mathrm{Hj}$ Baiq Isvie ajang pemilihan gubernur dan wakil Rupaeda, itu merupakan sebagai gubernur Nusa Tenggara Barat langkah awal telah membawa wajah periode 2018-2023.

baru bagi perpolitikan Provinsi Nusa Posisi Rohmi sebagai wakil Tenggara Barat. Peluang-peluang gubernur sekarang tidaklah mudah perempuan sebagai pemantik untuk di raih dengan begitu saja, semangat mereka untuk tanpa ada perjuangan dalam memaksimalkan potensi mereka medisain komunikasi politik yang sebagai calon penerus-penerus. Ini terbentuk dalam kampanye politik

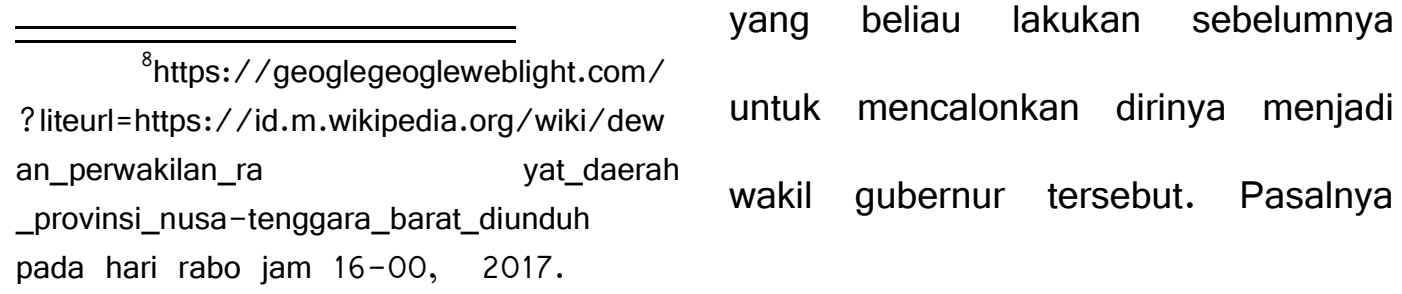


Komunike, Volume XI, No. 1, Juni 2019

sebuah fakta dalam masyarakat berusaha membawa tema atau topik Nusa Tenggara Barat dengan sosial tertentu untuk ditawarkan pada budaya yang masih kental serta masyarakat. Sebagian dari kita adat istiadat yang masih dijunjung mungkin lebih familiar dengan janjitinggi membuat tingkah laku dan janji politik. Hal ini bisa jadi benar, pola hidup mereka tetap karena itu merupakan bagian dari berlandaskan adat istiadat yang pesan dalam kampanye politik, mereka anut. Budaya patriarki yang meski tidak selalu bermakna masih memandang perempuan demikian.

sebagai orang-orang yang tergolong Kepemimpinan politik perempuan dalam golongan the second class Sasak terdapat dalam keluarga, atau penomorduaan atas hak-hak kaum dan kekerabatan. individual kaum perempuan Kedudukannya sangat sentral, menampak diberbagai domain karena ia garis penentu dan kehidupan termasuk dalam dunia pengontrol kekuasaan, sebenarnya politik. ${ }^{9}$ Tentu ini menjadi hambatan pengaruhnya sangat besar. Dalam terbesar dalam mempersiapkan kekuasaan perempuan sasak terlihat kampanye politik yang akan bahwa kekuasaan itu bukan sesuatu dilakukan. Hal yang paling yang bersifat publik atau formal signifikan dilakukan dalam atau impersonal, tetapi the personal kampanye politik adalah tentang is political. Kekuasaan dapat pesan-pesan yang disampaikan ditentukan secara personal, tak oleh kandidat. Masing-masing jarang berdiplomasi, proses tawar menawar justru terjadi di dalam pengantar studi Gender, (Mataram: LKIM ruang pribadi, yaitu kamar tidur. IAIN Mataram, 2005), hlm. 12. 
Untuk selanjutnya, kekuasaan yang terpisah-pisah dalam lingkup mikro (Keluarga) ini dapat meluas ke lingkup makro (publik), salah satunya melalui jaringan matrilokal. ${ }^{10}$ Proses ini sudah diluar ruang lingkup yang dapat mencerminkan nilai nilai demokrasi sebetulnya. Dengan munculnya calon Perempuan itu secara tidak langsung akan merusak struktur sosial dan budaya dikelompok tersebut, khususnya di wilayah Nusa Tenggara Barat.

B. Profil Dr.Hj Sitti Rohmi Djalillah, M.Pd

Nama : Dr.Hj Sitti Rohmi Djalillah, M.Pd, Tempat, Tanggal Lahir: Mataram, 29 November 1968 Jenis Kelamin : Perempuan Status Perkawinan : Kawin Agama Islam Alamat Rumah

Jl.

Kartini No RA 10, Kelurahan rakam, kabupaten Lombok Timur, NTB Alamat Kantor

10 Ibid, hlm. 203.
TGKH. Zainuddin Abdul Majid No. 132 Pancor, Selong, Lombok Timur. No kontak 081917927567, Email :

sittirohmidjalilah@yahoo.com,

MedSos : FB, WA, INSTAGRAM, Hoby :

Berorganisasi, Olah Raga, seni, Traveling

Riwayat Pendidikan :

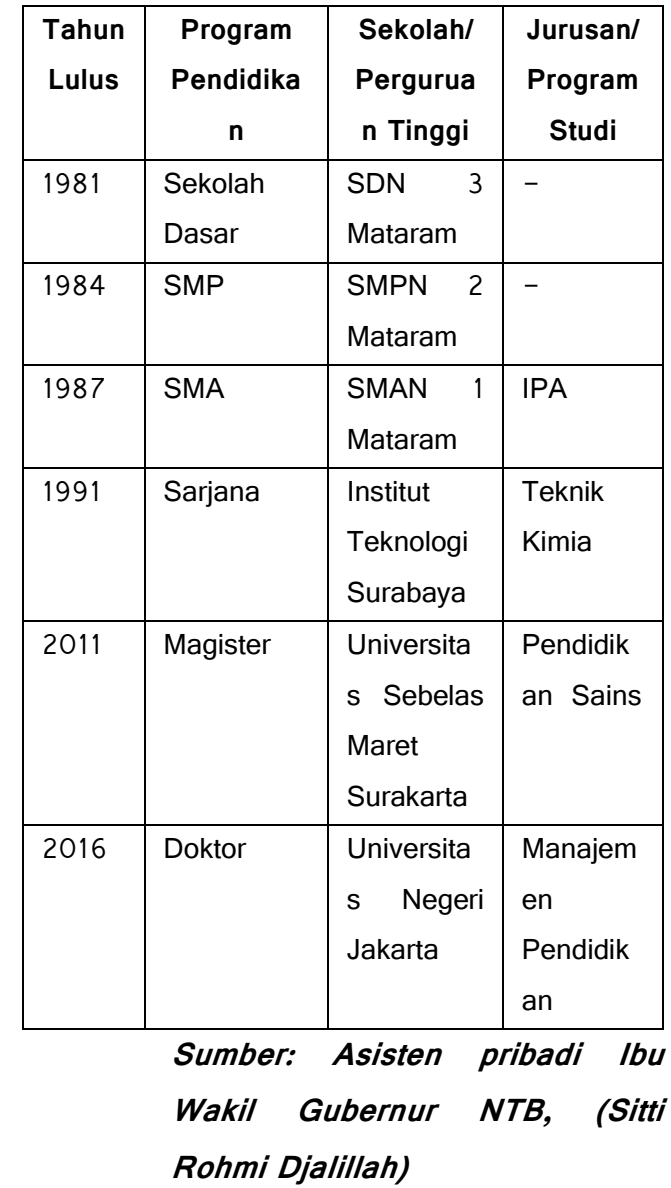

Dr. Hj.Sitti Rohmi Djalilah M.Pd JI. atau yang lebih akrab dipanggil umi Rohmi adalah Wakil Gubernur 
Komunike, Volume XI, No. 1, Juni 2019

Provinsi NTB periode 2018-2023. (SDN) 3 Mataram pada tahun Umi rohmi lahir di Pancor, Selong, 1981. Umi rohmi menjalani masa Lombok Timur, Nusa Tenggara kecilnya di Mataram. Setelah Barat 29 November 1968 , dari dewasa umi Rohmi pun melepas pasangan HM. Djalaludin (alm) masa lajangnya dengan seorang dan Siti Rauhun Abdul Madjid. Dia lelaki yang bernama H. M. Khairul menyelesaikan pendidikan Strata Rizal S.T, M.Kom, kebahagiannya satu pada Fakultas Teknik di pun tidak berhenti sampai disana, Institut Teknologi Surabaya Tahun karena umi rohmi dikarunia tiga 1999, dan Lulus Magister orang anak, anak pertama Pendidikan Sains pada Universitas bernama, H. Abdul Bassith Sebelas Maret Surakarta tahun Asdjazzi, Lc, Rania Amani, dan 2011. Dan pada tahun 2016 umi Muhammad Nabiel Rahmani. Lahir rohmi menyelesaikan program dari keluarga yang memiliki balutan Doktor nya dengan jurusan agama yang sangat kental sejak manajemen pendidikan di kecil pun umi rohmi sudah dididik Universitas Negeri Jakarta. betul oleh seorang kakek yang tak Sebelumnya umi Rohmi lain kemarin 2018 kakek Umi menyelesaikan studi pada Sekolah Rohmi Maulanasyaikh Tuan Guru Menengah Atas Negeri ( SMAN) Kyai Haji Muhammad Zainudin 1 Mataram tahun 1987, dan Abdul Madjid, di berikan gelar Sekolah Menengah Pertama Negeri sebagai Pahlawan Nasional, karena (SMPN) 2 Mataram pada tahun beliau adalah pendiri Nahdlatul 1984. Setelah menyelesaikan Wathan merupakan Organisasi pendidikan Sekolah Dasar Negeri 
Massa Islam terbesar di pulau dihasilkan oleh perusahaan lain. ${ }^{11}$ Lombok.

Dalam positioning, suatu produk akan direkam oleh konsumen dalam

C. Positioning Politik.

Positioning bagian dari strategi, dimana dalam dunia persaingan dimaksudkan untuk meraih kemenangan. Sebagai strategi dalam persaingan, positioning menjadi sangat penting keberadaanya. Hal ini bukan semata untuk menunjukkan posisi, tetapi lebih dari itu untuk menanamkan brand ke benak masyarakat yang menjadi sasaran. Selain sebagai strategi, positioning sesungguhnya merupakan bagian dari ilmu marketing yang sebelumnya sangat populer di dunia bisnis, yaitu semua aktifitas yang dimaksudkan untuk menanamkan kesan kepada para konsumen agar mereka dapat membedakan produk yang dihasilkan oleh perusahaan tertentu dengan produk yang

bentuk kesan atau image sehingga mereka pun dapat dengan mudah mengidentifikasinya. Semakin tinggi kesan produk yang direkam, maka semakin mudah pula mengingat produk tersebut. Tentu saja menanamkan kesan ke konsumen tidak terbatas pada produk saja, bisa berupa kredibilitas dan reputasi pelayan, kepuasan konsumen dan sebagainya.

Konsep ini kemudian diadopsi dalam dunia politik. Pengertiannya pun sesungguhnya tidak terlalu jauh berbeda, yaitu dari persaingan ekonomi menjadi persaingan politik. Dalam persaingan politik. Dalam persaingan politik juga diperlukan strategi positioning. Partai atau kandidat harus mampu menanamkan

\begin{tabular}{lccc}
\hline & Firmanzah, & Mengelola & Politik; \\
Komunikasi & dan & positioning & Politik, \\
( Jakarta: & Yayasan & Pustaka & Obor \\
Indonesia, 2011 ), hlm. & $164-167$. &
\end{tabular}


Komunike, Volume XI, No. 1, Juni 2019

kesan dan image politik kepada dipilih. Memilih satu kandidat tidak masyarakat. Tujuannya, agar partai akan menghasilkan sesuatu yang atau kandidat bersangkutan mudah berbeda dibandingkan ketika diingat dan menjadi pilihan masyarakat memilih kandidat lain masyarakat. Untuk dapat tertanam, jika semua kandidat punya tentu saja image tersebut harus karakteristik yang sama. Karena itu, memiliki sesuatu yang berbeda, keberadaan positioning politik sangat unik dan menarik daripada partai berguna sebagai pembeda antara atau kandidat lainnya. Image suatu satu caleg dengan caleg lain, kandidat harus memiliki sehingga akan timbul kesan khusus karakteristik tersendiri dibandingkan yang tertanam dalam benak kandidat-kandidat lain. masyarakat.

Perempuan sebagai caleg Menurut Worcester dan Baines seyogyanya memiliki sesuatu yang (2006) sebagaimana dikutip oleh berbeda daripada caleg-caleg lain, Firmanzah, semua aktifitas politik entah itu caleg laki-laki ataupun adalah aktifitas untuk memposisikan perempuan. Keragaman pilihan tentu diri dan mereposisikan diri, dengan akan menyulitkan masyarakat dalam semua aktifitas itu untuk menentukan pilihan politiknya. mendefiniskan identitas suatu partai Apalagi bila semua caleg memiliki atau kandidat. ${ }^{12}$ Ketepatan membuat karakteristik yang sama dan tidak positioning dalam hal yang ada yang menampilkan sesuatu menyangkut image politik, produk yang berbeda jelas akan membuat politik, pesan politik dan program masyarakat semakin sulit kerja akan membantu pula dalam menentukan siapa yang harus

12 Ibid, hlm, 219. 
penciptaan identitas politik. Artinya, direkam. Baik buruknya kinerja selain sebagai media untuk kandidat diukur dari perspektif diferensiasi, positioning politik juga pemilih. Posisi yang kuat dalam membantu dalam mendefinisikan benak masyarakat membuat suatu identitas. Iklim persaingan politik kandidat selalu diingat dan menjadi seperti pemilu menuntut adanya refrensi bagi masyarakat ketika reposisi identitas ini agar identitas mereka dihadapkan pada kandidat dapat dipersepsikan serangkaian pilihan. Menjadi refrensi dengan berbeda oleh masyarakat. berarti kandidat tersebut menjadi Masyarakat akan membandingkan yang pertama kali muncul dalam identitas satu kandidat dengan benak masyarakat. Karena itu, kandidat lain. Caleg perempuan pemilu sebetulnya pertarungan dalam pemilu seyogyanya harus positioning antar partai ataupun mampu melakukan proses ini agar antar kandidat.

terwujud track record yang kuat di Positioning politik secara tidak benak pemilih. Positioning image langsung dapat menjadi parameter politik bisa berupa program kerja, keterpilihan kandidat. Sama halnya isu politik atau image dalam dunia bisnis, posisi produk kepemimpinan. menjadi tolak ukur ketertarikan Masing-masing kandidat konsumen pada produk tersebut. berusaha menjadi yang dominan Dalam persaingan politik, yang dan menguasai benak masyarakat menang adalah pihak yang dalam pemilu. Dalam benak mendapat dukungan terbesar. pemilih, semua aktifitas yang Dengan demikian, mengejar dilakukan oleh kandidat akan kemenangan berarti kandidat harus 
Komunike, Volume XI, No. 1, Juni 2019

mampu melakukan positioning dalam siapa yang akan dipilih. Kejelasan benak masyarakat luas. Rendahnya posisi kandidat akan memudahkan keterpilihan perempuan di Nusa pemilih membedakan satu kandidat Tenggara Barat pada pemilu yang dengan kandidat-kandidat lain, (2) lalu penting untuk dilihat dari positioning politik yang jelas perspektif positioning ini. Seberapa membantu kandidat sendiri jauh relevansi kandidat perempuan membentuk identitas mereka. (3) menempatkan kesan dirinya ke membantu penyusunan strategi masyarakat dengan tingkat approach ke masyarakat, dan (4) keterpilihan mereka. Mereka tidak membantu dalam mengarahkan jenis hanya bersaing dengan sesama sumber daya politik apa yang perempuan, tetapi juga dengan dibutuhkan. ${ }^{13}$

kandidat laki-laki tentu kekuatan

strategi positioning amat penting.

D. Kampanye Politik

Mereka dituntut memunculkan

Pada pemilihan umum tidak sesuatu yang beda daripada caleg terlepas dari kegiatan kampanye. perempuan maupun caleg laki-laki Kampanye dan pemilu bagai dua yang lain, yaitu keunggulankeunggulan dan menanamkannya dalam bentuk masyarakat. Itulah pentingnya strategi positioning politik dalam persaingan politik seperti pemilu, yaitu positioning politik akan membantu sisi mata uang yang tidak bisa dipisahkan satu sama lain. Kampanye adalah sebuah tindakan doktrin bertujuan mendapatkan pencapaian dukungan. Usaha kampanye bisa dilakukan perorangan atau sekelompok orang masyarakat dalam menentukan

13 Ibid, hlm, 217. 
yang terorganisir untuk melakukan dibatasi, sifat gagasan terbuka pencapaian suatu proses pengambil untuk diperdebatkan khalayak, keputusan di dalam suatu tujuannya tegas, variatif serta kelompok, kampanye juga bisa spesifik, modus penerimaan pesan dilakukan guna untuk sukarela dan persuasi, modus mempengaruhi, penghambatan, tindakannya diatur kaidah dan kode pembelokan pencapaian. $^{14}$

etiknya, sifat kepentingan

Kampanye politik, adalah bentuk mempertimbangkan kedua belah komunikasi politik yang dilakukan pihak.

orang atau kelompok (organisasi) Metode kampanye yang dalam waktu tertentu untuk dilakukan oleh peserta pemulu memperoleh dan memperkuat adalah dalam bentuk : Pertemuan dukungan politik dari rakyat atau terbatas, Tatap muka, Penyiaran pemilih. Menurut Rogers dan melalui media cetak dan media Storey, merupakan serangkaian elektronik, Penyebaran bahan tindakan komunikasi yang terencana kampanye kepada umum, dengan tujuan menciptakan efek Pemasangan alat peraga di tempat tertentu pada sejumlah besar umum, Rapat umumndan Kegiatan khalayak yang dilakukan secara lain yang tidak melanggar peraturan berkelanjutan pada kurun waktu perundang-undangan. ${ }^{15}$ tertentu, sehingga kampanye cirinya Pelaksanaan kampanye dalam sumber yang melakukannya jelas, bentuk pertemuan terbatas, tatap waktu pelaksanaan terikat dan muka penyebaran melalui media

\begin{tabular}{lll}
\hline \multicolumn{1}{c}{14} & & \multicolumn{1}{c}{ Rozali Abdullah, Mewujudkan } \\
http:digilib.unila.ac.id/10792/15/BAB\%20II.p & Pemilu yang Lebih Berkualitas (Pemilu \\
df. Diakses Kamis 14 Februari 2019 & Legislatif), (Jakarta: Rajawali Pers, \\
jam 11:14 WITA & 2009), hlm. 200.
\end{tabular}


Komunike, Volume XI, No. 1, Juni 2019

cetak dan media elektronik, penyiaran melalui radio dan atau televise, penyebaran bahan kampanye kepada umum, dapat dilaksanakan sejak 3 (tiga) hari kerja setelah peserta pemilu ditetapkan sebagai peserta pemilu sampai dengan dimulainya masa tenang. Sedangkan rapat umum dilaksanakan selama 21 (dua puluh satu) hari kerja sebelum hari dan tanggal pemungutan suara. Ketentuan ini antara lain bertujuan untuk mengatasi masalah "mencuri start" sebagaimana sering terjadi pada pemilu tahun 2004 sehingga pada pemilu yang akan datang yang akan dijadwalkan selama 21 (dua puluh satu) hari, hanya rapat umum, sedangkan bentuk kampanye lain dapat dilaksanakan sejak 3 (3) hari kerja, setelah ditetapkan peserta pemilu. ${ }^{16}$

16 Ibid, hlm. 201.

\section{E. Teori Komunikasi Politik dan Islam}

Communication means that information, ideas, emotion, skills, stc. By the use of symbolword, pictures, figures, grapes, ect." ( pemindahan informasi, ide, emosi, keterampilan dan lain-lain dengan menggunakan symbol seperti kata foto-foto, figur-figur atau gerafik)..$^{17}$

Komunikasi proses intraksi sosial yang digunakan orang untuk menyusun makna yang merupakan citra mereka mengenai dunia (yang berdasarkan itu mereka bertindak) dan untuk bertukar citra itu melalui simbol-simbol. ${ }^{18}$

Komunikasi merupakan suatu proses penyampaian pesan dalam bentuk lambang yang bermakna, sebagai panduan pikiran serta

\footnotetext{
17 Ibid, hlm.53.

18 Jalaluddin Rahmat, Komunikasi

Politik Komunikator Pesan Dan Media (Bandung: PT Remaja Rosdakarya 2005 ), hlm. 6.
} 
Komunike, Volume XI, No. 1, Juni 2019

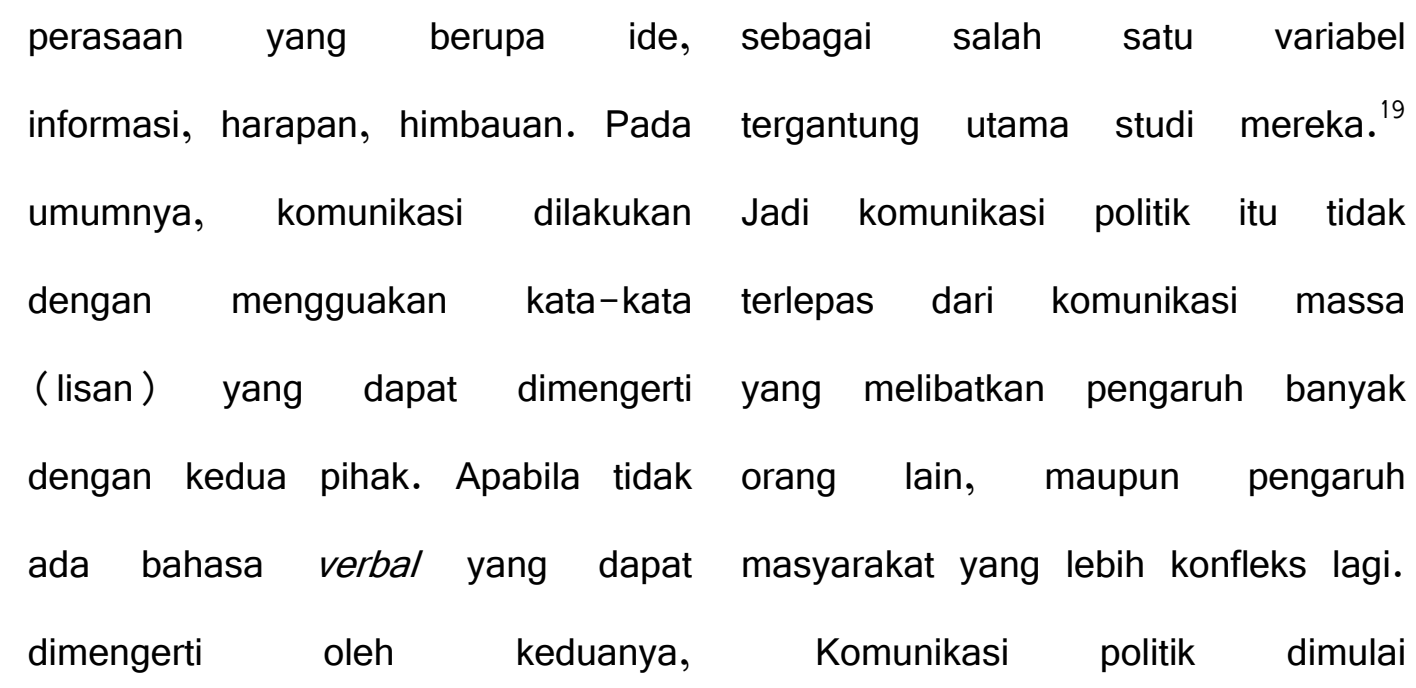
komunkasi bisa dilakukan dengan dengan mempelajari efek media menggunakan gerak-gerik badan, cetak dan radio terhadap pilihan menunjukkan sikap tertentu misalnya suara individu, seperti dalam Erie tersenyum, menggelengkan kepala County Study tahun 1940, bidang mengangkat bahu dan lain ini telah diperluas untuk mencakup sebagainnya. Cara seperti ini aspek-aspek lain komunikasi dan dinamakan komunikasi nonverbal. perilaku, media cetak yang sudah Permulaan study komunikasi, bertransformasi menjadi media komunikasi massa, dan komunikasi sosial. Facebook, instagram, politik saling terkait. Semua punya tweeter. Adapun radio sekarang ketertarikan intelektual yang sama sudah berubah menjadi televisi. ${ }^{20}$ pada efek komunikasi media Adapun pendapat para ahli massa. Sejak periode awal dari mengenai komunikasi politik : apa yang kemudian diidentifikasi Alwi Dahlan memaparkan sebagai studi komunikasi, para bahwa, komunikasi politik

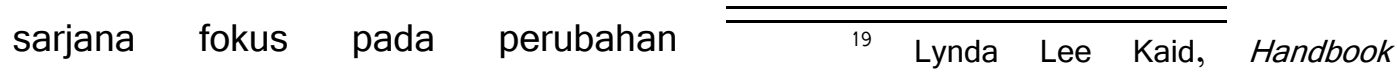
perilaku politik. (seperti memilih) Penelitian Komunikasi Politik, (Bandung: Nusa Media, 2015), hlm. 4. 20 Ibid, hlm. 3. 
Komunike, Volume XI, No. 1, Juni 2019

merupakan bidang atau disiplin sidang pengadilan atau saling yang menelaah prilaku dan kegiatan mempengaruhi sehingga bersifat komunikasi yang bersifat politik, kegiatan antar personal. Kemudian mempunyai akibat politik, atau berkembang menjadi kegiatan berpengaruh terhadap perilaku komunikasi massa yaitu berpidato politik. $^{21}$

kepada khalayak. ${ }^{23}$ Ada tiga jenis

Ramlan Surbakti mengemukakan retorika menurut Aristoteles dalam bahwa komunikasi politik adalah karyanya Retorika. Retorika proses penyampaian informasi diliberatif yaitu dirancang untuk mengenai politik dari pemerintah mepengaruhi khalayak dalam kepada masyarakat dan dari kebijakan pemerintahan yang masyarakat kepada pemerintah. ${ }^{22}$ fokuskan pada keuntungan atau Terdapat beberapa bentuk kerugian jika sebuah kebijakan komunikasi politik yang dilakukan diputuskan atau dilaksanakan, oleh komunikator infrastruktur politik Retorika forensic, yang berkaitan unuk mencapai tujuan politiknya dengan keputusan pengadilan, yaitu: Retorika, berasal dari bahasa Retorika demonstrative, yang yunani rhetorica, yang berarti seni mengembangkan wacana yang berbicara, asalnya digunakan dalam dapat memuji atau menghujat. ${ }^{24}$ perdebatan-perdebatan di ruang Agitasi Politik berasal dari bahasa Agitare artinya bergerak

21 Alwi Dahlan, Perkembangan

Komunikasi Politik Sebagai Bidang Kajian dalam Jurnal IImu Politik No. 6 , Kerjasama AIPI, LIPI, (Jakarta: Gramedia, 1990), hlm. 60. IImu Politik, ( Jakarta: Grasindo, 2010), hlm. 152. 
Komunike, Volume XI, No. 1, Juni 2019

atau menggerakkan, dalam bahasa khalayak dengan dengan ucapan inggris agitation. Menurut Harbert dan tulisannya. ${ }^{25}$

Blumer agitasi beoperasi untuk Propaganda, berasal dari kata membangkitkan rakyat kepada suatu latin Propagare (menanamkan gerakan politik, baik lisan maupun tunas suatu tanaman). Propaganda tulisan dengan merangsang dan adalah orang yang melakukan membangkitkan emosi khalayak. propaganda yang melakukan Dimulai dengan cara membuat propaganda yang mampu kontradiksi dalam masyarakat dan menjangkau khalayak kolektif lebih menggerakkan khalayak untuk besar, biasanya dilakukan politikus menentang kenyataan hidup yang atau kader partai politik yang dialami selama ini (penuh memilki kemampuan dalam ketidakpastian dan penuh melakukan sugesti kepada khalayak penderitaan) dengan tujuan dan menciptakan suasana yang menimbulkan kegelisahan dikalangan mudah terkena sugesti, di Negara massa. Orang yang melakukan demokratis menurut W. Dobb agitasi disebut agitator yang oleh dipahami sebagai suatu usaha Nepheus Smith disebut sebagai individu atau kelompok yang orang yang berusaha menimbulkan berkepentingan untuk mengontrol ketidakpuasan, kegelisahan atau sikap kelompok individu lainnya pemberontakan orang lain. Ada dengan menggunakan sugesti. agitator yang sikapnya selalu Sedangkan Harbert Blumer, suatu gelisah dan agresif, ada juga yang kampanye politik dengan sengaja lebih tenang, cendrung pendiam mengajak, mempengaruhi guna tetapi mampu menggerakkan 
Komunike, Volume XI, No. 1, Juni 2019

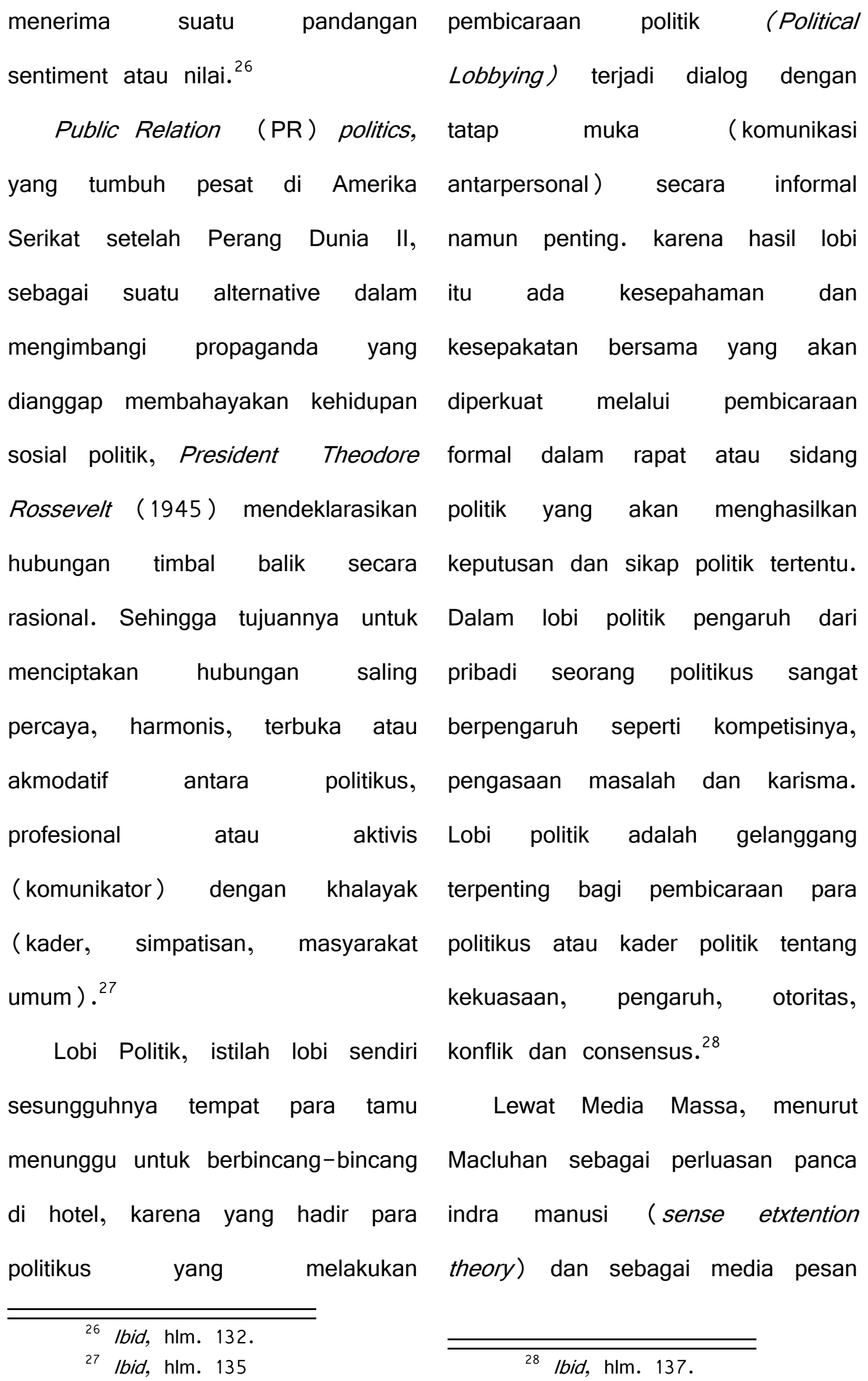


politik untuk mendapatkan media bisa memberikan kontribusi kepada pesan (the medium in the suatu organisasi yang dipimpinnya. message) dalam hal ini pesan Strategi komunikasi dalam politik politik untuk mendaptkan pengaruh, merupakan salah satu kunci kekuasan otoritas, membentuk dan keberhasilan sebuah tujuan politik. merubah opini publik atau dukungan Dalam melakukan persiapan pemilu serta citra politik, untuk kahayak 2018 pasalnya umi Rohmi yang lebih luas atau yang tidak melakukan berbagai upaya untuk bisa terjangkau oleh bentuk mendulang suara yang sebanyakkomunikasi yang lain. ${ }^{29}$ banyaknya, bersaing dengan caloncalon yang lain untuk memperoleh

F. Bentuk-Bentuk Kampanye Politik Dr. Hj Sitti Rohmi Djalillah Dalam Kontestasi Pemilihan Gubernur Menjadi wakil gubernur merupakan jabatan tertinggi kedua dalam satu organisasi karena wakil ibarat seorang copilot yang membantu pilot dalam membawa sebuah pesawat melewati mega, dan rintangan yang ada dengan penumpang yang berasal dari berbagai wilayah. Wakil memiliki tanggung jawab yang besar untuk

29 Ibid, hlm. 140. suara masyarakat sehingga suara tersebut mengahantarkannya menjadi wakil gubernur saat ini.

Kampanye pada prinsipnya merupakan suatu proses kegiatan komunikasi individu atau kelompok yang dilakukan secara terlembaga dan bertujuan untuk menciptakan suatau efek atau dampak tertentu.

Berbagai cara yang ditempuh dalam memperebutkan suatu kepemimpinan salah satunya bersosialisasi ketengah masyarakat entah itu melalui cara apapun yang 
Komunike, Volume XI, No. 1, Juni 2019

penting bisa memberi kepercayaan melalui cara-cara di bawah ini pada masyarakat. Pada pemilu antara lain: Menyebarluaskan 2018 umi rohmi memilih partai Tabloid. Tabloid ini diterbitkan Demokrat sebagai partai yang bisa untuk memperkenalkan sosok menghantarkannya menuju kursi pasangan calon nomor urut 3 ini orang penting nomor dua di sendiri, berisikan visi dan misi. Provinsi NTB saat ini. Menyampaikan keinginan dan Adapun bentuk-bentuk tujuan yang ingin dicapai melalui kampanye yang dilakukan oleh umi sebuah tabloid, tabloid ini dibuat Rohmi antara lain:

1. Mensosialisasikan Diri Kepada Masyarakat

Menjadi penantang baru tentu bukanlah suatu hal yang mudah bagi umi Rohmi, pasalnya umi rohmi dan pasangannya masih sendiri berbentuk majalah dan baru di mata masyarakat NTB, Koran. Seperti yang disampaikan tidak seperti para pasangan calon oleh umi Rohmi sebagai berikut : lainnya yang cukup familiar di "Tabloid ini murni dibuat mata masyarakat NTB dan oleh tim pemenangan saya, masing-masing pasangan calon kebanyakan kan kalau calon-calon ada yang menjadi bupati, walikota lain menggunakan jasa-jasa dan sebagainya. Tidak dikenalnya koran, TV, tapi kalau saya tidak oleh masyarakat umi Rohmi lantas murni kerja tim, dan tim yang mengatasi permasalahan tersebut mengeksekusi itu semua isi dari 
Komunike, Volume XI, No. 1, Juni 2019

tabloid ini dihasilkan dari kunjungan-kunjungan ke dusundusun, desa-desa, dan kampungkampung yang pernah saya kunjungi untuk berkampanye. Cara menyebarluaskan tabloid ini dibawa langsung ketika berkampanye, baik ketika saya dan tim yang pergi untuk berkampanye, atau pasangan calon saya juga, dan tim pemenangan juga tetap membawa tabloid itu untuk dibagikan kepada masyarakat agar masyarakat bisa mengenal saya sebagai calon wakil gubernur mereka dan pembeda dari pasangan calon lainnya. itu bukan hanya sebatas tabloid biasa yang dibagikan kepada masyarakat namun tabloid itu memuat mulai dari janji pembangunan sampai janji-janji untuk kemudahan masyarakat dari pendidikan sampai dengan kesehatan". 30
Tabloid ini keluar satu bulan sekali karena isi dari tabloid tersebut berisikan tawaran yang akan menjawab permasalahan yang terjadi di tengah masyarakat NTB. Kedua. Menggunakan Media Sosial. Untuk menghasilkan kerja yang maksimal jadi dibutuhkan sebuah usaha yang kiat, begitupun hal yang dilakukan oleh umi Rohmi dan TIM pemenangannya. Tidak hanya media cetak yang digunakan dalam mensosialisasikan dirinya kepada masyarakat, media elektronik pun dimanfaat dengan baik oleh umi Rohmi dan tim pemenangan, media elektronik yang lebih sering digunakan oleh umi Rohmi disini adalah Facebook, WA, dan Instagram. Media cetak seperti Facebook, WA, dan Instagram tersebut merupakan media yang paling 
Komunike, Volume XI, No. 1, Juni 2019

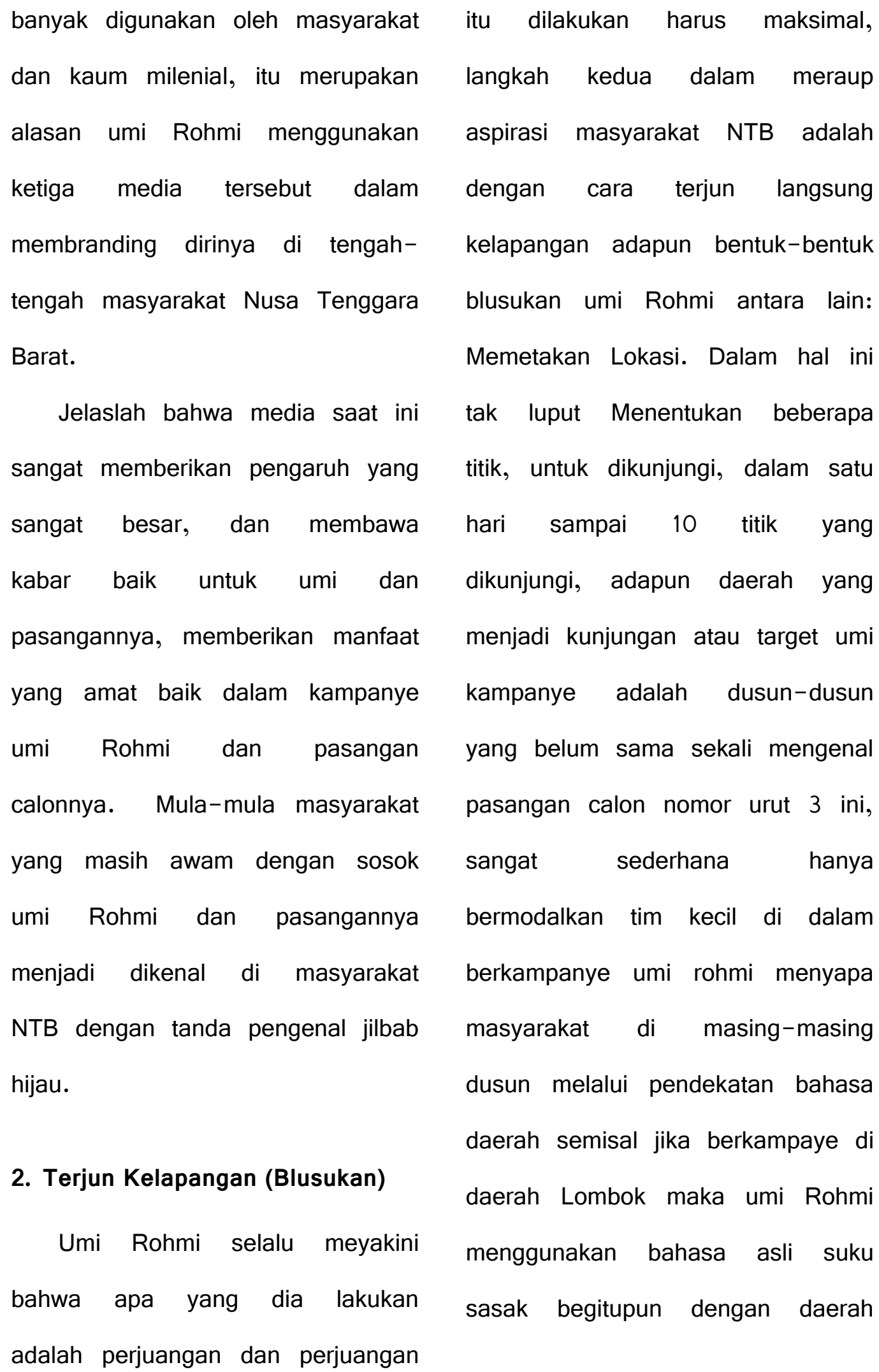


Komunike, Volume XI, No. 1, Juni 2019

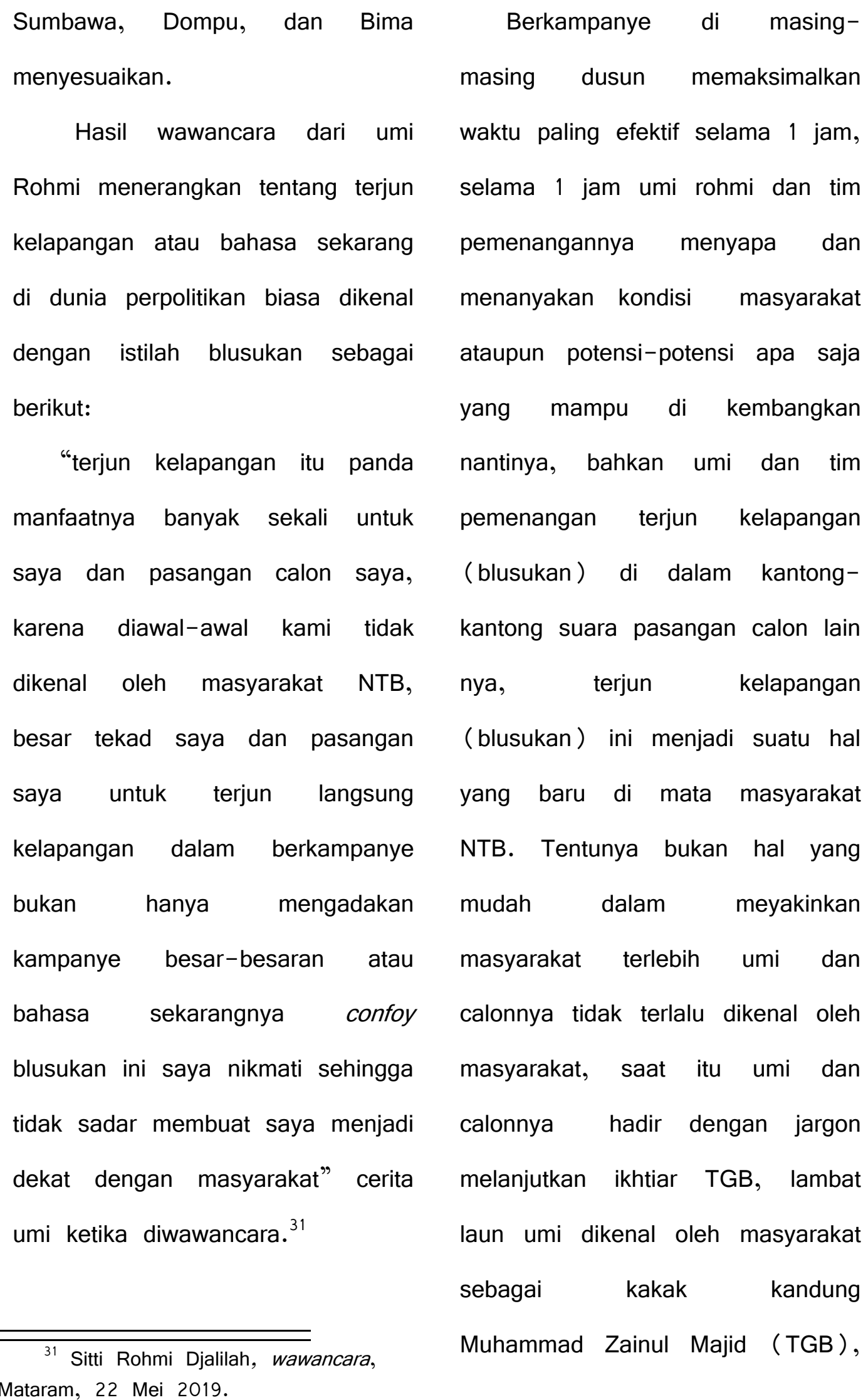


Komunike, Volume XI, No. 1, Juni 2019

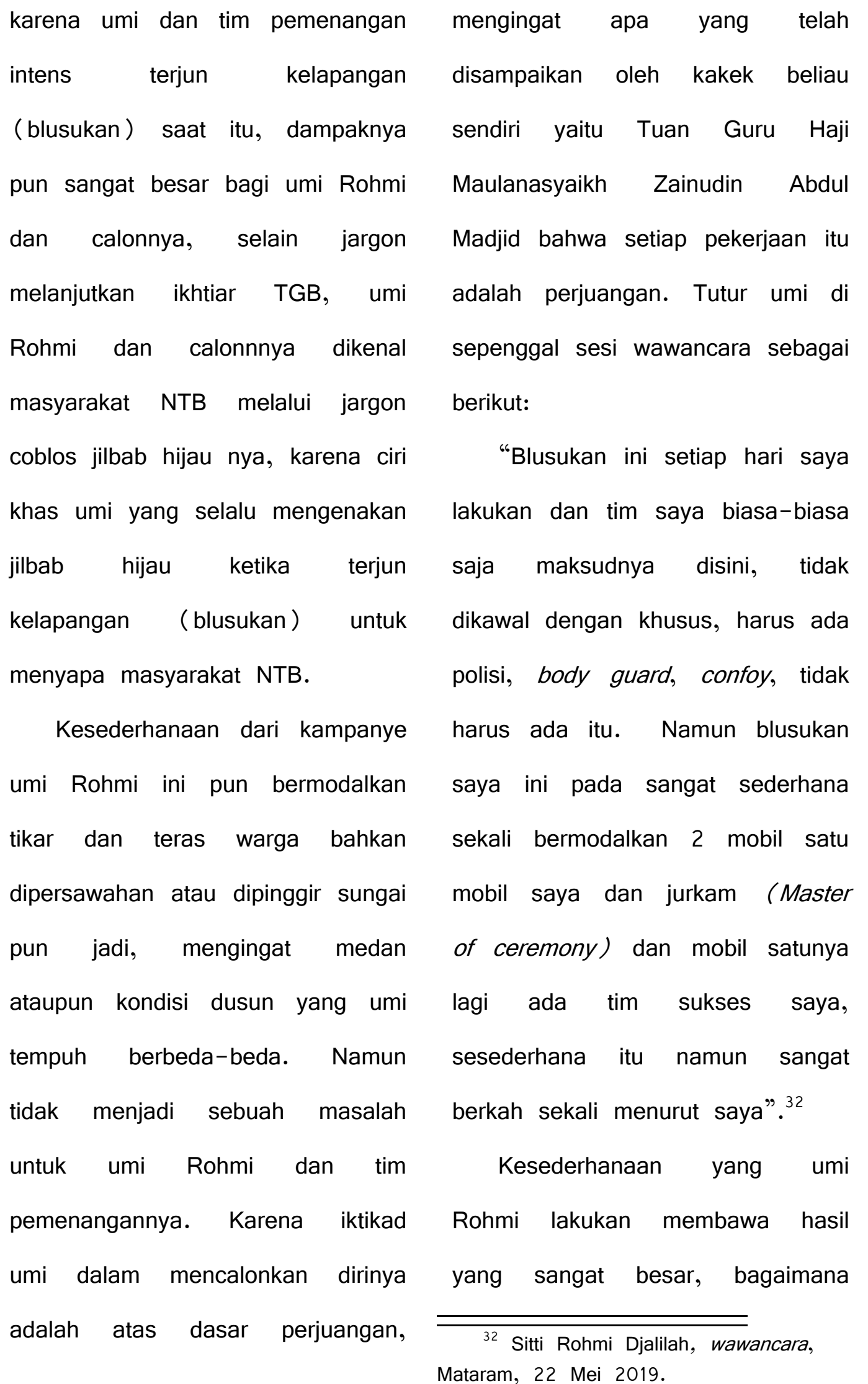


Komunike, Volume XI, No. 1, Juni 2019

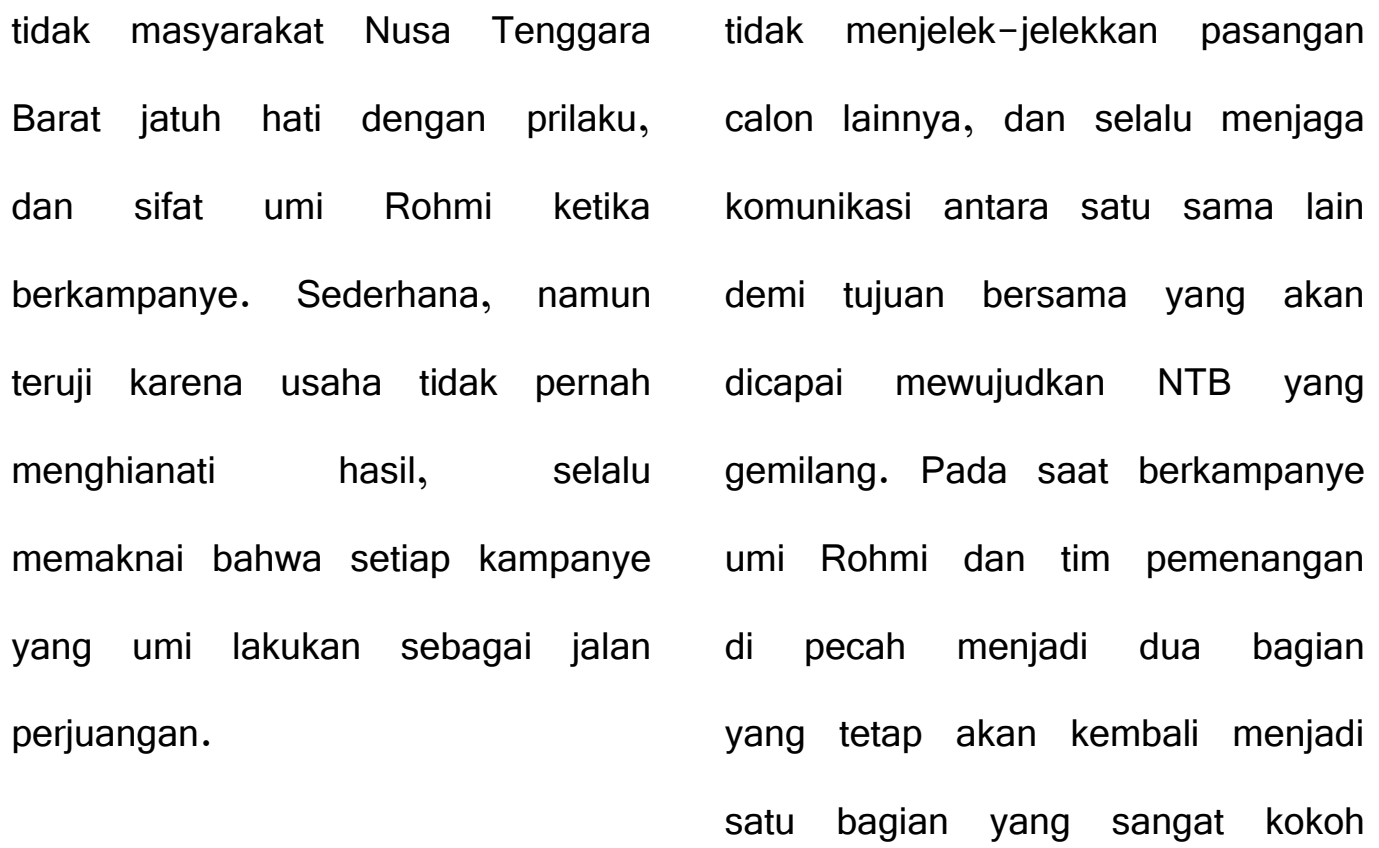

Kerja, Bersinergi Dengan Tim Sukses Tempat yang diduduki umi Rohmi saat ini tidak serta merta atas dasar kinerjanya semata namun tidak luput dari tim pemenangannya, yang dimana umi Rohmi dan tim pemenangan membagi tugas masing-masing antara lain: Menjalin Komunikasi Yang Baik. Bagi umi Rohmi tim pemenangan yang dibentuk saat itu sangatlah solid dan harmonis, umi Rohmi selalu menekankan kepada setiap tim pemenangan yang akan di pecah nantiya untuk nantinya, umi berjalan dengan tim pemenangan skala kecil yang sebelumnya telah dilakukan pemetaan wilayah yang mana harus di jangkau oleh umi dan tim pemenangan yang skala kecil sedangkan tim pemenangan yang telah di pecah melakukan pemetaan wilayah mana yang akan di jangkau oleh umi selanjutnya.

G. Isi Pesan-Pesan Kampanye Dr. Hj Sitti Rohmi Djalillah Dalam Kontestasi Pemilihan Gubernur 
Komunike, Volume XI, No. 1, Juni 2019

Terhitung bahwa umi rohmi "ketika saya mencalonkan diri merupakan kakak kandung dari sebagai wakil gubernur mungkin mantan Gubernur NTB yaitu bisa dibilang hanya masyarakat Muhammad Zainul Majdi atau yang Lombok timur yang mengenal saya biasa di sapa TGB. Tidak mampu dan itu tidak secara keseluruhan, untuk dielakkan bahwa TGB dan elektabilitas saya pada waktu menjabat selama dua periode itu hanya $14 \%$, namun ketika saya menjadi gubernur Nusa Tenggara berkampanye dan terjun langsung Barat terhitung dari 2008-2013 ke lapangan terus-menerus dan tak sampai 2013-2018. Siapa yang lupa bahasa yang saya gunakan tidak mengenal sosok TGB, TGB selalu saya sesuaikan dengan merupakan salah satu tokoh daerah yang saya kunjungi misanya panutan masyarakat NTB yang kalau di Lombok berarti saya namanya terus melambung di level menggunakan bahasa sasak untuk nasional. Sehingga keberadaan dari berkomunikasi dengan mereka, TGB ini memberikan pengaruh kalau di Sumbawa, cukup kalimatbesar terhadap kakak beliau yakni kalimat familiar dan pembuka umi Rohmi ketika mencalonkan diri suasana yang saya pakai apa sebagai wakil Gubernur. Bagaimana rungan?, sehat sia serea ke papin, tidak pernyataan tersebut langsung bapak, ibu? Beda lagi kalau di saya dapatkan dari umi Rohmi Dompu, dan Bima intinya wakil Gubernur NTB saat ini, ketika menyesuaikan agar mereka welcome saya mewawancarai beliau diruang dengan keberadaan saya. Di awal kerja kantor Gubernur NTB. cukup dengan ucapan saya kakak kandung dari TGB insya allah akan 
Komunike, Volume XI, No. 1, Juni 2019

melanjutkan ikhtiar dari TGB selalu semakin besar yang kita hadapai begitu yang saya katakana dan maka kita akan menjadi sosok Alhamdulillah elektabilitas saya yang tangguh, tetap istiqomah dan meningkat drastis, Tutur umi. ${ }^{33}$ berdoa. Ketika berkampanye isi

Pasangan cerdas yang mewakili pesan yang saya sampaikan selain kelompok muda dan sering dikenal dari melanjutkan ikhtiar dari adik dengan jilbab hijau ini semakin saya $T G B$, isi pesan saya bahwa memikat hati masyarakat NTB, saya satu-satunya calon wakil terlihat jelas bahwa hanya umi Gubernur perempuan. Ini Rohmi petarung yang berasal dari kesempatan untuk kita buktikan kaum perempuan, namun itu tidak bahwa perempuan itu bisa, dan menyurutkan semangat beliau untuk mampu, apabila bersungguhmengikuti kontestasi pemilihan sungguh. Pada masa TGB hak-hak gubernur, jelasnya: perempuan sudah di akomodir "tantangan itu jangan pernah sudah banyak kepala-kepala Dinas dijadikan sebagai ketakutan dan itu dari kalangan perempuan, yang ins akan menjadi masalah didalam shaa allah akan saya perkuat dirimu, namun jadikan tantangan itu lagi. Mungkin tidak terlau banyak untuk menjadi penguji bagi dirimu, isi pesan tentang perempuan yang sehingga dari sana kita akan tahu saya bawa, saya hanya bahwa disini kurangnya saya saya menekankan mari perbaiki bersamaharus siapkan ini, itu dan sama, bantu saya dalam mengatasi sebagainya bahkan itu akan masalah perempuan yang ada di menjadi sangat menantang ketika NTB ini. Kebanyakan yang

\footnotetext{
${ }^{33}$ Sitti Rohmi Djalilah, wawancara, disampaikan bagaimana membangun Mataram, 22 Mei 2019.
} 
Komunike, Volume XI, No. 1, Juni 2019

NTB menjadi lebih baik lagi, hadirnya sosok perempuan akan masyarakat NTB pun mampu menjadi keterwakilan kalangan menilai dan melihat bahwa perempuan nantinya di birokrasi. kehadiran saya pun sudah menjadi Visi-misi gubernur saat ini keterwakilan perempuan. ${ }^{34}$ merupakan representasi dari visiMenjadi satu-satunya petarung misi ketika kampanye kemarin dari kalangan perempuan membuat dengan sebutan NTB GEMILANG. umi Rohmi percaya diri, bahwa NTB Gemilang ini merupakan tantangan ketika umi Rohmi singkatan dari gerakan mencintai mencalonkan diri sebagai wakil lingkungan, kesehatan, dan Gubernur NTB mampu untuk pendidikan cemerlang.

ditaklukkan, semakin besar NTB GEMILANG merupakan visi tantangan yang dihadapi semakin pembangunan sekaligus komitmen kuat, dan kokoh karakter dirinya. dan ikhtiar untuk mewujudkan NTB Pesan yang disampaikan pun tidak yang tertata rapi sebagai tempat terlalu banyak tentang isu gender, hunian menyenangkan, dengan hanya sebagian sebagai pembangkit masyarakat yang berdaya saing, semangat untuk kaum perempuan. tangguh, dan berbudi luhur serta Umi Rohmi selalu percaya bahwa pemerintahan yang berorientasi pada kehadirannya sudah menjadi pesan pelayanan publik.

untuk masyarakat terlebih Umi Rohmi dan pasangannya perempuan di NTB, terlebih menjabarakannya kedalam 6 misi masyarakat NTB sudah pintar-pintar pembangunan dan 52 program untuk memaknai bahwa dengan unggulan daerah, yang telah

\footnotetext{
34 Sitti Rohmi Djalilah, wawancara, dituangkan kedalam dokumen Mataram, 22 Mei 2019.
} 
perencanaan RPJMD Provinsi NTB, bersih, diwujudkan melalui program

2019-2023.

Pertama, mewujudkan NTB tersedianya ruang atau akses bagi tangguh dan mantap. Melalui seluruh masyarakat untuk dapat penguatan mitigasi bencana dan berpartisipasi dan berkreasi pengembangan infrastruktur serta membangun NTB. Bahkan pemprov konektivitas wilayah. Pemerintahan NTB juga menyediakan ruang yang umi rohmi dan pasangannya telah luas bagi masyarakat untuk dapat melaunching 8 program unggulan menyampaikan keluh kesah dan untuk NTB gemilang infrastruktur berinterkasi secara langsung dan tangguh bencana yakni. maupun secara digital dengan umi Percepatan jalan mantap, SPAM rohmi dan calonya bersama regional, Penerapan sistem jajarannya. Dengan demikian, informasi siaga bencana atau SI- diharapkan birokrasi benar-benar AGA, Irigasi cukup, Desa tangguh hadir ditengah masyarakat guna bencana, Sekolah siaga bencana. ${ }^{35}$ member solusi dan melayani. Kedua, mewujudkan NTB bersih Komitmen untuk mennghadirkan dan melayani, melalui transformasi birokrasi yang bersih dan melayani birokrasi yang berintegritas, tersebut, diimplementasikan oleh berkinerja tinggi, bersih dari $\mathrm{KKN}$, umi Rohmi dan pasangannya dan berdedikasi. Komitmen untuk melalui penerapan konsep menghadirkan pemerintahan yang pemerintahan yang berbasis

\section{$\overline{35}$}

https: / /diskominfotik.ntbprov.go.id/content/n tb-gemilang-dijabarkan-pada-6-misi-52program-unggulan Diakses kamis 23 Mei 2019 elektronik (SPBE) sebagai wahana untuk memperlancar pelayanan dan mepermudah berbagai aktivitas / 
Komunike, Volume XI, No. 1, Juni 2019

interaksi sosial. Program unggulan bangsa dan bahkan pemimpin gemilang birokrasi ini meliputi 9 dunia. Selain dari 1000 cendikia, program yang berbasis digital yaitu: juga terdapat Sembilan program eNTeBe Plan, SAKIP LEVEL A, strategis lainnya, yakni: Literasi E-Samsat, NTB Care, Research digital, Rumah bahasa, Revitalisasi based policy, Samsat delivery, NTB posyandu, NTB juara, Air bersih SDGs centre, NTB Satu Data, NTB untuk semua, Jamban keluarga, Satu peta dan NTB WTP. ${ }^{36}$

Re- engineering SMK, Generasi

Ketiga, mewujudkan NTB sehta emas NTB dan Rumah layak dan cerdas melalui peningkatan huni. $^{37}$

kualitas sumber daya manusia Keempat, mewujudkan NTB asri sebagai pondasi daya saing daerah. dan lestari melalui pengelolaan Umi rohmi dan pasangannya telah sumber daya alam dan lingkungan menetapkan 10 program unggulan yang berkelanjutan. Terdapat 6 Gemilang pendidikan dan program unggulan gemilang kesehatan. Salah satu diantaranya lingkungan yang menjadi fokus adalah 1000 cendikia, dimana penanganan secara kolaboratif, baik putra-putri NTB setiap tahun dikirim antara pemerintah Provinsi dan keluar negeri untuk menimba ilmu kabupaten kota, maupun stakeholder dan memperkuat mindset, sehingga lainnya.

kelak setelah kembali ketanah air, Mulai dari gerakan sadar siap menjadi pemimpin-pemimpin lingkungan hingga program aksi

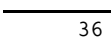

https: / /diskominfotik.ntbprov.go.id/content/n tb-gemilang-dijabarkan-pada-6-misi-52program-unggulan Diakses kamis 23 Mei 2019

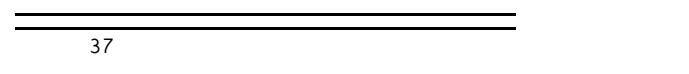

https://diskominfotik.ntbprov.go.id/content/n tb-gemilang-dijabarkan-pada-6-misi-52program-unggulan Diakses kamis 23 Mei 2019 
pengendalian

pencemaran

lingkungan, khususnya sampah

plastic dan limbah insdustri melalui

$$
\text { gerake }
$$

program tersebut meliputi: perizinan dan bermuara pada

Pembangunan tata ruang secara penurunan tingkat pengangguran

berkelanjutan, NTB hujau, NTB terbuka. Industri yang

Zero waste, Geopark dunia, Bank dikembangkan, fokus pada industri sampah dan Taman asri. ${ }^{38} \quad$ olahan dan permesinan yang

Kelima, mewujudkan NTB mendukung nilai tambah terhadap

Sejahtera dan mandiri melalui berbagai produk dari sektor penanggulangan kemiskinan, pertanian, pariwisata, dan lapangan mengurangi kesenjangan, dan usaha industry lainnya. misalnya pertumbuhan ekonomi iklusif mesin-mesin untuk sarana produksi bertumpu pada pertanian, pariwisata pertanian, seperti traktor, alat dan industry.

Menurut pasangan calon Umi pabrik penggilingan, dan industri Rohmi industrialisasi merupakan pengolahan lainnya, harus kunci mewujudkan masyarakat NTB diproduksi atau di assamble oleh yang sejahtera dan mandiri. putra-putri NTB di daerah sendiri. Indikatornya adalah pertumbuhan Dan sedapat mungkin dikurangi industry, dan sasarannya adalah import dari luar. Didalam RPJMD

$=38$

https: / /diskominfotik.ntbprov.go.id/content/n tb-gemilang-dijabarkan-pada-6-misi-52program-unggulan Diakses kamis 23 Mei 2019
Provinsi NTB tahun 2019-2023, sesuai janji kampanye yang disampaikan umi Rohmi dan 
Komunike, Volume XI, No. 1, Juni 2019

pasangannya telah menetapkan 18 gemilang pembangunan sosial program unggulan gemilang budaya, yaitu: Islamic centre pusat ekonomi, pariwisata, pertanian dan peradaban, Kampong madani, Desa industri. Terdiri dari: Melawan bersinar, Kampong media, Bale kemiskinan dari desa, Hasil hutan mediasi, Kota layak anak, Sekolah bukan kayu (HHBK) unggul, $E-$ perjumpaan, Ramah difable dan Commerce, Bumdes maju, Science PAUD holistik integratif. ${ }^{40}$ technology industrial park (STIP) inovatif, Koperasi aktif, Keluarga sasambo gemilang, NTB ramah investasi, UMKM bersaing, Desa wisata, Perda produk local, Rumah kemasan, Pertanian lestari, Kampung unggas, Revitalisasi BLK, Apartemen ikan, KRPL dan Industrialisasi produk pertanian. ${ }^{39}$ Keenam, mewujudkan NTB aman dan berkah melalui pengembangan masyarakat madani dan beriman, berkarakter dan penegakan hukum yang berkeadilan. Terdapat 9 program unggulan

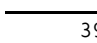

https: / /diskominfotik.ntbprov.go.id/content/n tb-gemilang-dijabarkan-pada-6-misi-52program-unggulan Diakses kamis 23 Mei 2019

\section{H. Kesimpulan}

$$
\text { Sebagai seorang perempuan }
$$
yang akan maju dalam pilgub 2018 umi Rohmi mengontrol untuk mencapai target kemenangan menggunakan beberapa komunikasi karena perempuan masih dipandang sebagai mahluk second class mahluk kedua di daerah Nusa Tenggara Barat jadi umi Rohmi menggunakan beberapa cara seperti bentuk kampanye yang dilakukannya mulai dari memperkenalkan (mensosialisasikan) diri kepada

https://diskominfotik.ntbprov.go.id/content/n tb-gemilang-dijabarkan-pada-6-misi-52program-unggulan Diakses kamis 23 Mei 2019 
Komunike, Volume XI, No. 1, Juni 2019

masyarakat, terjun langsung pesan bahwa naiknya umi Rohmi kelapangan atau biasa dikenal dan pasangan calonnya sebagai dengan istilah blusukan, dan cagub dan wagub NTB adalah terakhir kerja, bersinergi dengan tim melanjutkan ikhtiar dari pemimpin sukses. Semua itu dilakukkanya yang menjabat sebagai gubernur dengan sangat baik karena dengan NTB sebelumnya.

cara tersebut umi Rohmi Keberhasilan dari membawa mengetahui apa saja yang sebuah pesan ingin melanjutkan dibutuhkan oleh masyarakat NTB, iktiar dari pemimpin yang menjabat umi Rohmi dan tim Pemenanganya sebelumnya sebagai gubernur NTB mampu membaca peta politik dan selama dua periode, sudah terukur kemauan serta hasrat dari berapa banyak masyarakat yang masyarakat NTB melalui ketiga cara mencintai pemimpin tersebut prestasi tersebut. Keberhasilan yang yang di torehkan untuk masyarakat dihasilkan oleh ketiga bentuk NTB terkenang sangat baik dalam kampanye tersebut terukur melalui sebuah memori ingatan masyarakat yang mana yang memiliki pengaruh NTB, sehingga ketika umi Rohmi yang sangat besar di hati dan pasangannya membawa pesan masyarakat dan pesan-pesan yang berbentuk ingin melanjutkan ikhtiar disampaikan untuk memenangkan dari sang adik kandung yaitu bapak pilgub 2018, ternyata dari ketiga TGB maka masyarakat NTB bentuk kampanye tersebut yang meyakini piihan dari bapak TGB paling besar perannya adalah tersebut merupakan pilihan blusukan atau terjun langsung masyarakat NTB pula. kelapangan, dengan disampaikan 
Komunike, Volume XI, No. 1, Juni 2019

\section{DAFTAR PUSTAKA}

Abdul Hamid Al-Ghazali, Pilar-Pilar Kebangkitan Umat (Jakarta: Al-I'tisom, 2001)

Alwi Dahlan, Perkembangan Komunikasi Politik Sebagai Bidang Kajian dalam Jurnal IImu Politik No. 6, Kerjasama AIPI, LIPI, ( Jakarta: Gramedia, 1990)

Alwisol, Psikologi Kepribadian Edisi

Revisi, (Malang: UMM Press, 2004)

Anwar Arifin, Komunikasi Politik 'Filsafat Paradigma Teori Tujuan Strategis dan Komunikasi Politik Indonesia', (Yogyakarta: Graha IImu, 2011)

Baiq Mirnawati, Komunikais Politik Partai Golkar Dalam Pemilihan Walikota dan Wakil Walikota Mataram Tahun 2015, (Skripsi, FDK IAIN Mataram, Mataram, 2016)

Baiq Ratna Manis, Calon Legislative (Caleg) Perempuan Dalam Perspektif Tokoh Adat Kecamatan Pujut Pada

Pemilihan Umum (PEMILU) Legislatif 2014 (Studi Kasus Pada Caleg Perempuan Dapil 3 Kecamatan Pujut Kabupaten
Lombok Tengah), (Skripsi, FDK IAIN Mataram, Mataram, 2015)

Cholid Narbuko dan H. Abu Achmadi, Metodologi Penelitian, (Jakarta: Bumi Aksara, 2008)

Firmanzah, Mengelola Politik; Komunikasi dan positioning Politik, (Jakarta: Yayasan Pustaka Obor Indonesia, 2011) Harjani, Hefni. Komunikasi Islam, ( Jakarta: Kencana, 2015)

Imam Hidajad, Teori-Teori Politik, (Malang: Setara Press, 2009) Jalaluddin Rahmat, Komunikasi Politik Komunikator Pesan Dan Media (Bandung: PT Remaja Rosdakarya 2005)

Komarudin Hidayat, Demokrasi dan Hak Asasi Manusia dan Masyarakat Madani (Jakarta: Kencana Group, 2006)

Lexy J Moleong, Metode Penelitian Kualitatif, (Bandung: PT Remaja Rosda Karya, 2001)

Anwar Arifin, IImu Komunikasi Sebuah Pengantar Ringkas ( Jakarta: $\quad$ PT Raja Grafindo,2002 )

Lynda Lee Kaid, Handbook Penelitian Komunikasi Politik, (Bandung: Nusa Media, 2015) 
Komunike, Volume XI, No. 1, Juni 2019

Masruchah, Catatan Perjuangan Ramlan Surbakti, Memahami IImu Politik Perempuan, (Jakartta Politik, (Jakarta: Grasindo, Selatan: Yayasan Jurnal 2010)

Perempuan, 2010)

Ridwan Umay Leky, Tradisi

Moelong J, Lexy, Metodologi Upacara Adat Perkawinan Suku

Penelitian Kualitatif, (Bandung: KUI Di Kecamatan Alor Barat

PT Remaja Rosda Karya,

Daya Kabupaten Alor Propinsi 2001)

Muhammad Kodri, Bolehkah Wanita Menjadi Imam Negara,

( Jakarta: Gema Insani Press, 1999)

Nusa Tenggara Timur Perspektif

Hukum Islam. Al-Ikhkam Jurnal

Ahwal al- Syahshiyah, Vol. vi,

Nomor 2, Desember 2015

Santi Wijaya Hesti Utami dkk,

Muhammad Mufid, Etika Dan

Perempuan Dalam Pusaran

Filsafat Komunikasi (Jakarta :

Demokrasi, (Yogyakarta: IP4

Kencana Perenada Mesia

Group, 2009 )

Lappera Indonesia, 2001)

Saparinah Sadli, Pengetahuan

Perempuan, (Jakarta Selatan:

Dan Pemikiran, (Bandung: CV

PUSTAKA SETIA, 2015)

Yayasan Jurnal Perempuan, 2006)

Nikmatullah dan Erma Suriani, Sugiyonno, Metode Penelitian pengantar studi Gender, Kuantitatif, Kualitatif, dan R\&D, (Mataram: LKIM IAIN Mataram, 2005 )

(Bandung: Alfabeta, 2009)

Supardi, Bacaan Cerdas Menyusun

Skripsi, (Yogyakarta: Kurnia

Nurul Zuriah, Metodologi Penelitian

Sosial dan Pendidikan (Jakarta:

Bumi Aksara, 2009)

Kalam Semesta, 2011)

Umaimah Wahid, Perempuan Dan

Kekuasaan Politik Perempuan

Phlipus, Ng Dan Nurul Aini,

Dalam Pemilukada DKI Jakarta

Sosiologi Dan Politik (Jakarta:

Tahun 2012. (Jakarta: Jurnal

PT Raja Grafindopersada,

Komunikasi Malaysian Journal 2004)

Of Communication 2013), Jilid

29. 
Komunike, Volume XI, No. 1, Juni 2019

Winengan, Seni Mengelola Dakwah,

(Mataram: pusat penelitian dan

publikasi ilmiah LP2M UIN

MATARAM, 2018)

Yusuf Zainal Abidin, Manajemen

Komunikasi, (Filosofi, Konsef,

Dan Aplikasi), (Bandung:

Pustaka Setia, 2015) 